\title{
A Novel WT1 Gene Mutation Associated with Wilms' Tumor and Congenital Male Genitourinary Malformation
}

\author{
JUN SAKAMOTO, AYAKO TAKATA, RYUJI FUKUZAWA, HARUHITO KIKUCHI, \\ MASAHIKO SUGIYAMA, YUTAKA KANAMORI, KOHEI HASHIZUME, JUN-ICHI HATA \\ Department of Pediatric Surgery, University of Tokyo Faculty of Medicine, Tokyo, Japan [J.S., M.S., Y.K., \\ K.H.]; Department of Pathology, Keio University School of Medicine, Tokyo, Japan [A.T., R.F., H.K., \\ J.H.]; and National Children's Medical Research Center, Tokyo, Japan [J.H.]
}

\begin{abstract}
WT1 is located on the short arm of human chromosome 11 and consists of 10 coding exons. Mutations of this gene have been reported to be the cause of Wilms' tumor, congenital male genitourinary malformations, and/or renal disorders. We describe here a novel $W T 1$ gene mutation, i.e. a point mutation at intron $7(+2)$ in both the tumor and the germline cells of a patient with Wilms' tumor and congenital male genitourinary malformation, but without renal disorder. The position of the mutation is at a splice donor site of intron 7 , which causes the splicing out of exon 7 and generates a truncated protein. This type of mutation in the WT1 zinc finger domain has not been reported before. The mutation is of paternal origin and is heterozygous in the germline cells. In the tumor cells, however, the maternal allele is largely lost, from $11 \mathrm{p} 12$ to $11 \mathrm{p} 15$, which results in maternal loss of
\end{abstract}

heterozygosity. These results, together with the data from previous reports, suggest that WT1 may function in gonadogenesis, nephrogenesis, and Wilms' tumor tumorigenesis. (Pediatr Res 50: 337-344, 2001)

WT, Wilms' tumor

Abbreviations:

GU, genitourinary

WT+GU, Wilms' tumor and congenital male genitourinary malformation in the absence of renal disorder

LOH, loss of heterozygosity

DDS, Denys-Drash syndrome

SSCP, single-strand conformation polymorphism

RFLP, restriction fragment length polymorphism
WT is an embryonal renal solid tumor that affects about 1 in 10,000 children (1) and accounts for about $6.5 \%$ of all childhood malignancies (2). The median age at onset is $38 \mathrm{mo}$, and nearly $80 \%$ of the patients develop the tumor before $5 \mathrm{y}$ of age (3). In patients with congenital malformations (e.g. aniridia), the age at diagnosis may be even earlier-before 30 mo (3).

WT1 has been localized to human chromosome $11 \mathrm{p} 13$ by positional cloning in studies of patients with WAGR (WT, aniridia, GU malformation, and mental retardation) syndrome $(4,5)$. The gene spans approximately $50 \mathrm{~kb}$ and contains 10 coding exons: exons 1-6 encode an amino-terminus Gln/Prorich domain, which may function in transcriptional suppression or activation, and exons 7-10 encode carboxyl-terminus four consecutive (Cys)2-(His)2 zinc finger domains, which share a high degree of homology with those of the early growth response gene $1(E G R 1)$ and have DNA binding activity that recognizes the same GC-rich target as $\operatorname{EGRl}(6,7)$ or a second

Received January 30, 2001; accepted May 24, 2001.

Correspondence and reprint requests: Jun-ichi Hata, National Children's Medical Research Center, 3-35-31 Taishido Setagaya-ku, Tokyo 154-8509, Japan; e-mail: jhata@nch.go.jp
TC-rich target (8). This gene product has four splicing isoforms, reflecting the presence or absence of two alternatively spliced exons [17 amino acids of exon 5 and the 3 amino acids, Lys-Thr-Ser (KTS), in the last part of exon 9]. The relative distribution among variants and respective binding ability to the target have been investigated in detail (9).

Although WT1 was initially thought to be the putative WT suppressor, the frequency of mutations in this gene in children with sporadic WT is $<10 \%(10)$. Therefore, recent attention has focused more on the role of WT1 in the development of the GU system and kidney rather than in tumorigenesis. A knockout study of murine $w t 1$ revealed failure of kidney and gonad development, and the result was lethal when the mutation was homozygous (11). Nevertheless, this gene is still considered to be related to WT tumorigenesis in cases with certain congenital anomalies $(3,12,13)$. WT and congenital male GU malformations, in particular, are postulated to be closely related, and the incidence of such malformations in WT patients is estimated to be much higher than in the general population $(3,14,15)$.

In the present study, we report a novel WT1 gene mutation in a case displaying unilateral WT and congenital male GU malformation in the absence of renal disorder (referred to 
"WT+GU" in this study), and we discuss the possible involvement of the WT1 protein in four WT1-related syndromes [Denys-Drash syndrome (DDS), WAGR syndrome, WT + GU, and Frasier syndrome (FS)] by comparing the data in the literature.

\section{MATERIALS AND METHODS}

\section{Patient}

The patient was a 1-y-old boy in whom ambiguous genitalia, hypospadias, and cryptorchism were noted at birth. No aniridia or any other anomalies were observed, and no signs of proteinuria or any other renal dysfunction have been detected to date (he is now $5 \mathrm{y}$ old). The patient's karyotype is $46 \mathrm{XY}$, and he has no family history of WT. He developed left unilateral WT at $1 \mathrm{y}$ of age, and was admitted to the University of Tokyo Hospital. The tumor was successfully removed and diagnosed as stage $\mathrm{I}(\mathrm{C} 1, \mathrm{~N} 0, \mathrm{~V} 0, \mathrm{U} 0, \mathrm{M} 0)$.

\section{DNA and RNA Preparation}

After obtaining informed consent, we collected tumor tissue samples and peripheral blood from the patient and his parents. As a control, normal kidney samples were collected from an aborted fetus with parental permission. All these procedures were approved by the Research Ethical Board of Keio University School of Medicine. Genomic DNA was isolated from tissue samples and peripheral blood lymphocytes by the phenol-chloroform method. Total RNA was extracted from the same specimens with ISOGEN (Wako Pure Chemicals, Tokyo, Japan) and purified by the thiocyanate method and DNase I treatment. cDNA libraries were synthesized with a First-Strand cDNA Synthesis Kit (Pharmacia, Uppsala, Sweden).

\section{Analysis of WT1 Gene}

Genomic DNA from each sample was digested by EcoRI and submitted to Southern blotting with the WT33 probe (16). PCR-SSCP analysis was performed for all 10 coding exons with appropriate PCR primers, as described previously (17, 18 ), with some modifications. The PCR products were denatured and resolved on a high-density nondenaturing gel $(20 \%$ total polyacrylamide, $30 \%$ ethylene glycol) using the PhastSystem (Pharmacia). Direct sequencing analysis without intermediate cloning steps was performed with the same samples using an A.L.F DNA Sequencer 2 (Pharmacia).

We used the reverse transcriptase (RT)-PCR method to identify mutant transcripts with a sense primer designed against exon 6 (5'-AACCACACAACGCCCATCCT-3') of the WT1 and antisense primers against exon 8 (5'-CTCCTTTGGTGTCTTTTGAGC-3') and exon 10 (5'-GCCACCGACAGCTGAAGGGC-3'). PCR was also performed with total RNAs without reverse transcriptase for negative controls. The RTPCR products were sequenced after subcloning to confirm the splicing errors.

\section{Immunohistochemistry}

After 3- $\mu \mathrm{m}$ thick serial paraffin sections of the fixed tumor specimens for immunohistochemistry were prepared, they were treated with $0.4 \%$ pepsin in $0.2 \mathrm{~N} \mathrm{HCl}$ for $30 \mathrm{~min}$ at $37^{\circ} \mathrm{C}$ and reacted with a 1:200 dilution of anti-human WT1 antibody, 6F-H2 (DAKO, Carpinteria, CA, U.S.A.), which recognizes the peptide corresponding to the $\mathrm{N}$-terminus 84 amino acid residues of WT1 for $18 \mathrm{~h}$ at $4^{\circ} \mathrm{C}$. After reaction with secondary antibody with peroxidase-labeled polymer, color was developed with Dotite DAB (Wako Pure Chemicals). Control sections were immunostained with nonimmune immunoglobulins, and immature glomeruli adjacent to the tumor were evaluated as an internal positive control. Immunohistochemistry of desmin and actin was then performed. Sections were also immunostained with anti-human D33 antibody or anti-human HHF35 antibody, respectively, as described above.

\section{Study of the LOH on Chromosome 11}

We investigated polymorphism to detect $\mathrm{LOH}$ on chromosome 11 and to determine which allele (paternal or maternal) had been lost. We identified 11 markers on chromosome 11 between 11q13 and 11p15, all of which could be examined by the PCR amplification method and were suitable for polymorphic analysis. We used the PhastSystem and high-density nondenaturing gels for denaturing PAGE. Some of the RFLP markers were resolved on 2\% agarose gels.

The markers used were PYGM (11q13) (19), D11S991 (11p11) (20), D11S554 (11p12) (21), WT1 (11p13) (17, 22), PAX6 (11p13) (23), BDNF (11p13) (24), D11S865 (11p14) (25), PTH (11p15) (26), TH (11p15) (27), IGF2 (11p15) (28), and $H 19$ (11p15) (29).

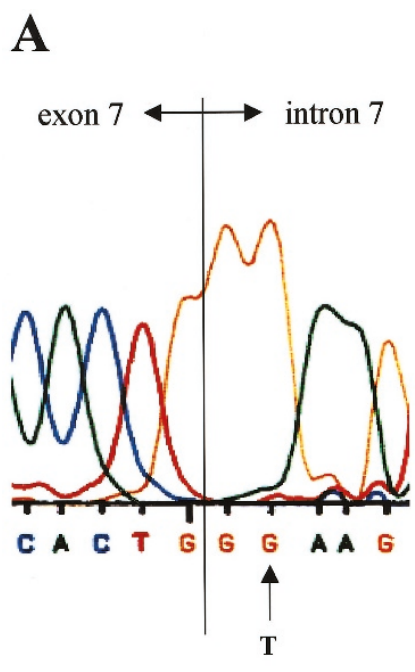

tumor

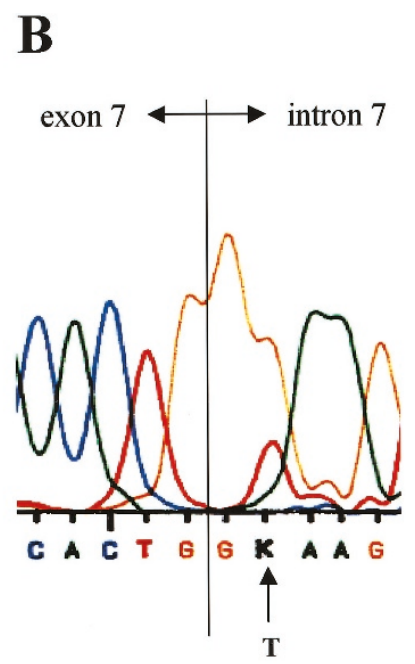

germline
Figure 1. Sequence of $W T 1$ intron 7 splice donor site in the tumor and the germline cells of the present case. (A) Mutation in the tumor cells. $\mathrm{T} \rightarrow \mathrm{G}$ mutation is recognized at intron $7(+2) .(B)$ Mutation in the germline cells. The " $\mathrm{K}$ " in the sequencing line means that the sequencer could not distinguish between $\mathrm{T}$ or $\mathrm{G}$ at this base. Hence, although the $\mathrm{T} \rightarrow \mathrm{G}$ mutation is recognized at the same position in the tumor cells, the sequencing data suggest the possibility of the heterozygosity at this base in the germline cells. 
RESULTS

\section{WT1 Mutation Analysis}

No deletions or mutations were detected by Southern blotting or PCR-SSCP analysis in WT1 coding exons from any of the samples (data not shown). However, direct sequencing revealed a point mutation at intron $7(+2, \mathrm{~T} \rightarrow \mathrm{G})$ in the patient's tumor cells (Fig. 1A) and the patient's peripheral blood lymphocytes (the germline cells) (Fig. 1B). In the germline cells, the sequencer showed the " $\mathrm{K}$ " at this position, which meant that the sequencer could not tell $\mathrm{T}$ or $\mathrm{G}$ at this base (Fig. $1 B$ ). This result strongly suggested that the point mutation was heterozygous in the germline cells.

Because intron $7(+2)$ is a splice donor site, a mutation at this position should induce splicing out of exon 7. Accordingly, RT-PCR was used to detect this splice error. Analysis with the primer-pairs for exon 6 and 8 should yield a 305-bp band if splicing is normal. However, if exon 7 is spliced out, the base pairs would be shortened to $154 \mathrm{bp}$ (Fig. 2A). The normal fetus kidney showed only a normal 305-bp band, whereas the tumor cells showed an aberrant 154-bp band (Fig. 2B). By contrast, both 305-bp and 154-bp bands were detected in the germline cells (Fig. 2B). These results also indicate that the mutation is heterozygous in the germline cells. Both bands were sequenced after subcloning passage, and the results confirmed that the products were consistent with the splicing theory described above (data not shown). When RT-PCR analysis was extended to exon 10 , a stop codon was detected at the beginning of exon 9 in the mutant mRNA due to a frame shift (Fig. 2C). The tumor showed two extra miss-splicing bands at positions between 305-bp and 154-bp, but these products were faint in intensity and not investigated further.

\section{Pathologic Findings and Immunohistochemical Study}

The size of the tumor was $11 \times 10 \times 9 \mathrm{~cm}$, and it weighed $511 \mathrm{~g}$. On gross section, the tumor was found to be centrally located in the left kidney. Microscopic examination of the tumor revealed a nephroblastoma with triphasic histology (Fig. $3 A$ ). Blastemal cells showed a nodular pattern, and were surrounded by rich stromal components, including ectopic myogenic cells (Fig. 3A). This myogenic differentiation was confirmed by desmin and actin immunohistochemistry (data not shown). The abortive regions, which suggested intralobar nephrogenic rests, were found at the margin of the tumor. No glomerular sclerotic changes were found in the normal kidney tissue removed with the tumor (data not shown).

We performed an immunohistochemical study to demonstrate the loss of DNA binding function of the aberrant WT1. The tumor and the nephrogenic rests did not stain with antiWT1 antibody (Fig. 3B), although the immature glomeruli adjacent to the tumor stained with the antibody (Fig. 3C).

\section{Polymorphic Analysis of Chromosome 11}

We then investigated whether the mutation detected in WT1 in the tumor cells was homozygous or hemizygous as a result of LOH. However, polymorphic analysis of WT1 region in all the DNA samples in this family was not informative (data not
A
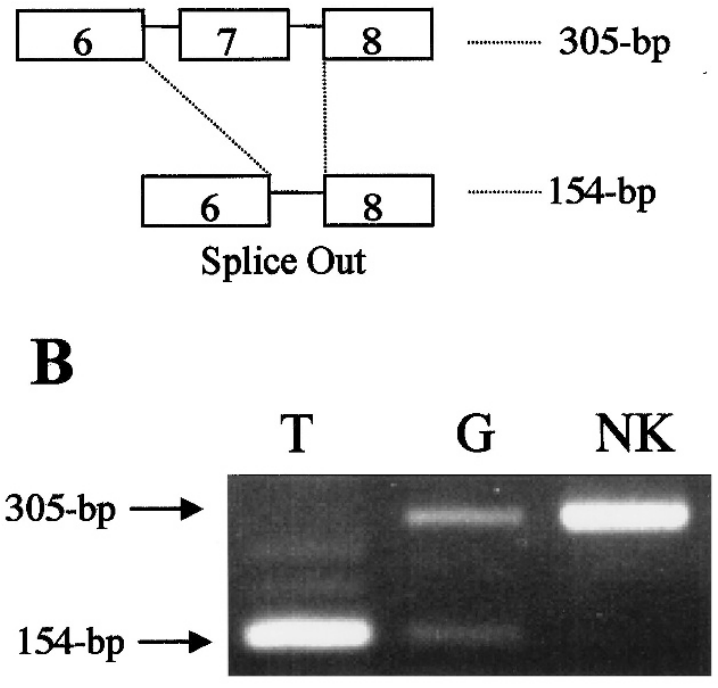

C

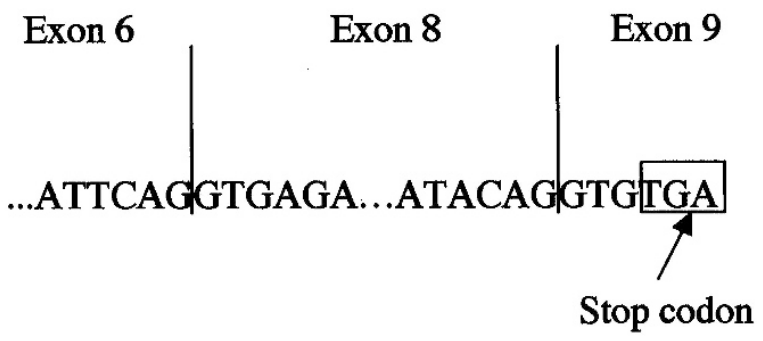

Figure 2. Mutant transcripts from the WT1 intron $7(+2)$ mutation. $(A)$ Illustration of the mutant transcripts. The rectangles represent exons, and the numbers in them represent those of each exon. Normal mRNA including exon 7 generates a 305-bp band, whereas aberrant mRNA in which exon 7 is spliced out generates a shorter 154-bp band. (B) RT-PCR at exon 6-8. The tumor cells show the aberrant 154-bp band instead of the intact 305-bp band, whereas the germline cells have both the 154-bp and 305-bp bands. The normal fetus kidney cells show only the 305-bp band. $T$, tumor; $G$, germline; $N K$, normal fetus kidney sample. $(C)$ Sequence of the aberrant mRNA in the tumor and the germline cells. The sequencer shows that exon 8 is directly connected to exon 6 and detects a stop codon (TGA) at the beginning of exon 9 due to a frame shift.

shown). We therefore selected 10 polymorphic markers on chromosome 11 encompassing WT1 between $11 \mathrm{q} 13$ and $11 \mathrm{p} 15$ (Fig. 4).

PYGM (11q13) showed a different genetic background between the father $\left(\mathrm{A} / \mathrm{A}^{\prime}\right)$ and the mother $\left(\mathrm{B} / \mathrm{B}^{\prime}\right)$. The patient's germline cells had received one of the alleles from each parent (A/B), and the tumor cells contained the same two alleles (A/B). We therefore concluded that heterozygosity was retained in the tumor cells at this region (Fig. 5A). On the other hand, although D11S554 (11p12) showed a similar tendency in the germline cells, one of the alleles inherited from his mother was lost in the tumor cells, indicating maternal $\mathrm{LOH}(\mathrm{mLOH})$ in this region (Fig. 5A). TH and IGF2 (both 11p15), which was electrophoresed on an agarose gel, also showed $\mathrm{mLOH}$ in this 


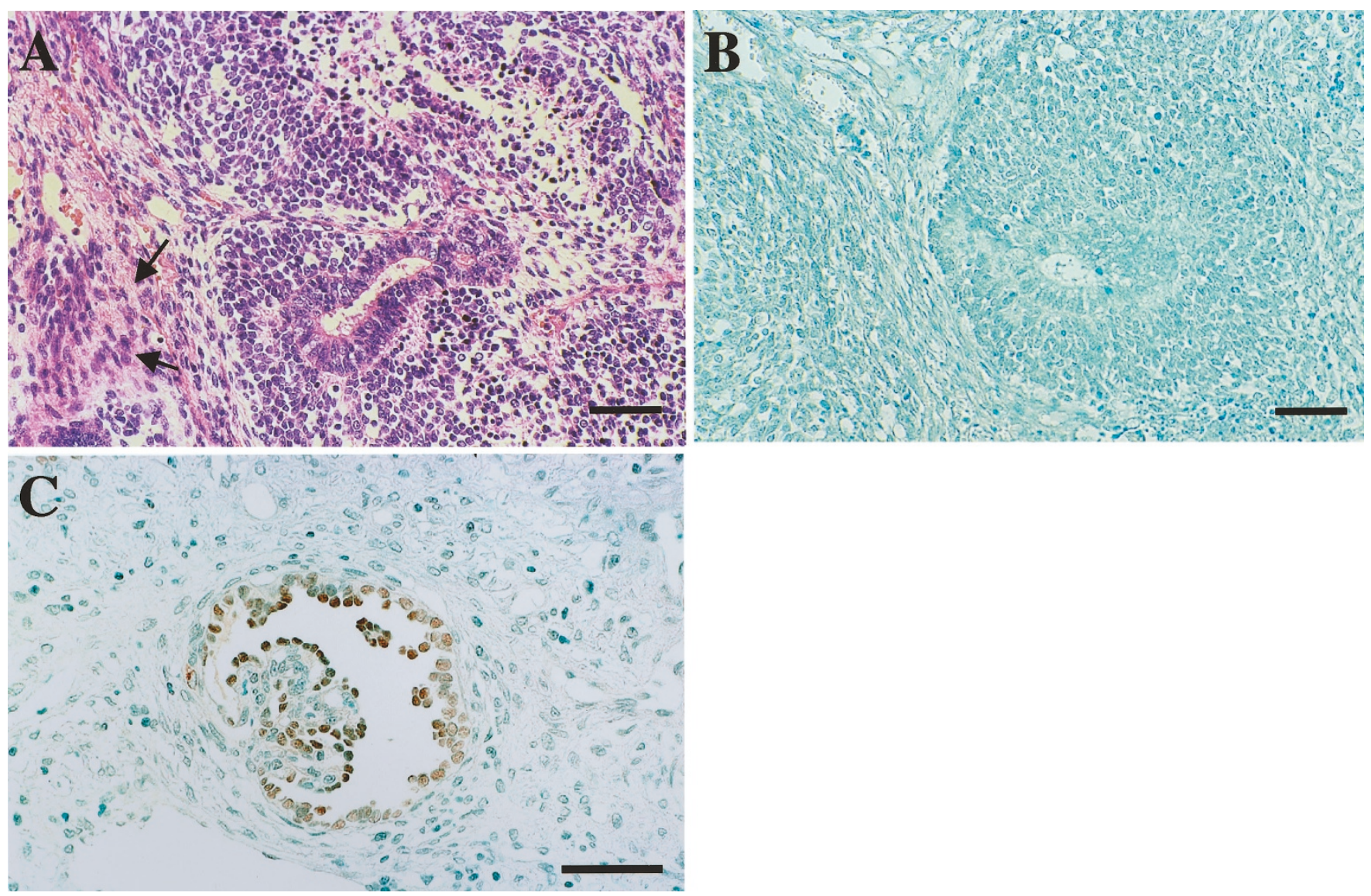

Figure 3. Histology of the tumor and immunohistochemistry in the present case. (A) Triphasic histology of the tumor. Ectopic myogenic cells are found in stromal components surrounding the blastemal cells (arrows). $(B)$ The tumor tissue is unstained by the anti-human WT1 antibody. (C) Immature glomerulus. The Bowman's capsule epithelium and podocytes are clearly stained. $(A)$ Hematoxylin and eosin stain; $(B, C)$ Immunohistochemistry with the anti-human WT1 antibody. Scale bars: $100 \mu \mathrm{m}$.

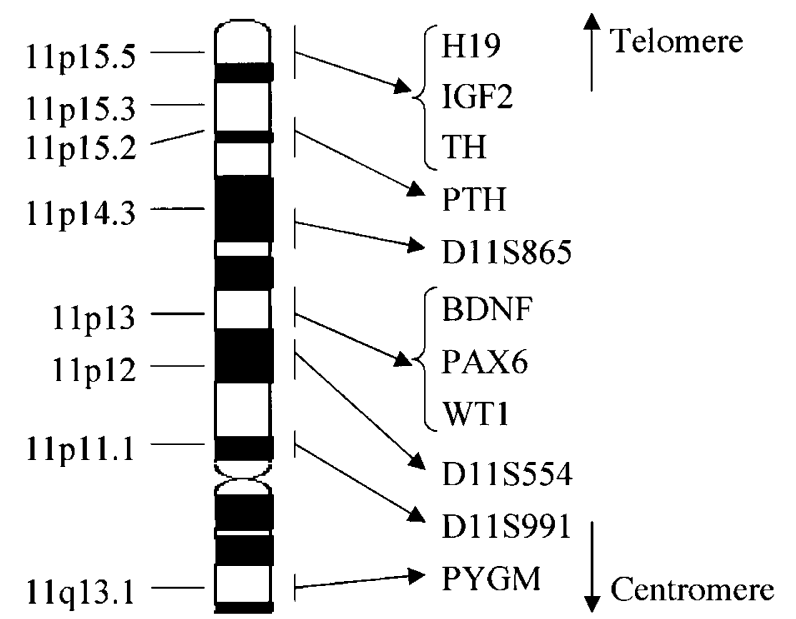

Figure 4. Site map of the loci analyzed in chromosome 11. The loci are arranged in order, top to bottom, from the telomere to the centromere of $11 \mathrm{p}$. PYGM at the bottom is a region in 11q (11q13).

region in the tumor cells (Fig. $5 B$ ). Together with the results for $P A X 6$ and $B D N F$ (both $11 \mathrm{p} 13$ ) (Fig. $5 A$ ), we concluded that both alleles were retained in the germline cells, and that the mutation, which was of paternal origin, was heterozygous. On the other hand, there was a broad loss of the maternal allele from $11 \mathrm{p} 12$ through $11 \mathrm{p} 15$ in the tumor cells that resulted in a hemizygous mutation (see Table 1). It is unclear whether this $\mathrm{mLOH}$ in the tumor cells was the result of a deletion or a mitotic recombination. The parental alleles were all apparently normal (data not shown).

\section{DISCUSSION}

In the present study, we demonstrated a novel $W T 1$ gene mutation in a patient with WT + GU. Polymorphic analysis indicated that the mutation was of paternal origin and heterozygous in the germline cells, whereas the maternal allele was largely lost in the tumor cells. This mutation was concluded to be de novo because the parental alleles were intact.

Concerning WT1 mutation in patients with $\mathrm{WT}+\mathrm{GU}$, only nine cases have been reported so far $(12,30-35)$. The genetic characteristics of these cases, including the present one, are summarized in Table 2. Different from the previous reports, the present case is the first with a splicing error in the zinc finger domain of $W T l$. In addition, we reviewed the literature and have summarized the characteristics of the four WT1-related syndromes in 46XY patients in Table 3, although the features described are limited to those that are most commonly observed and typical, e.g. Breslow et al. (36) reported that patients with $\mathrm{WT}+\mathrm{GU}$ have a moderate risk of long-term renal failure and that those with WAGR have a high risk of long- 
$\mathbf{A}$

PYGM

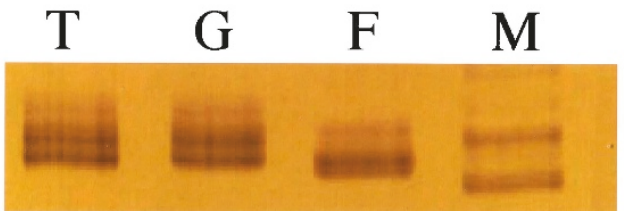

D11S991

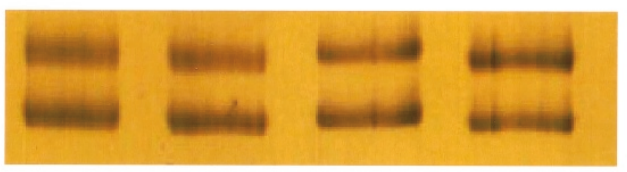

IGF2
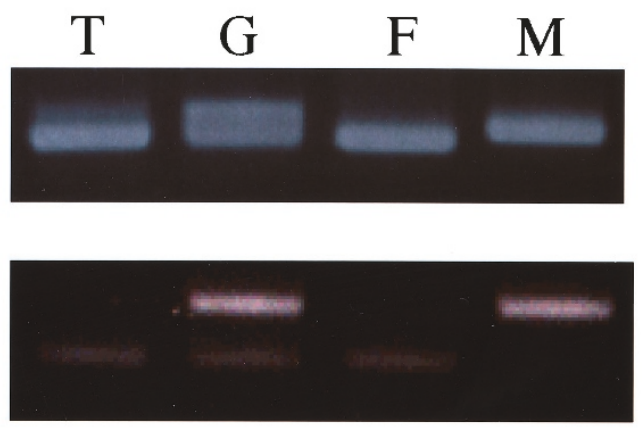

D11S554

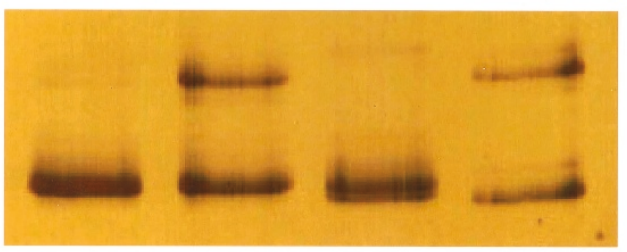

PAX6

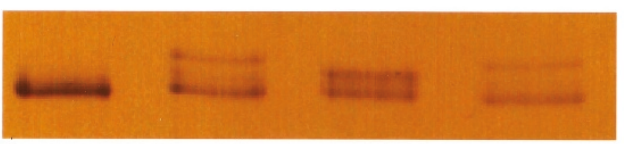

BDNF

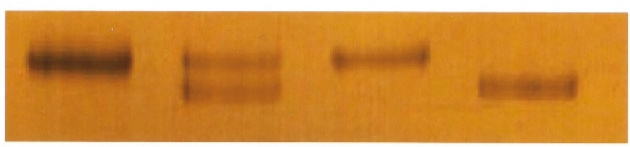

Figure 5. Polymorphism of the present case in the short arm of chromosome 11. The germline cells show retention of heterozygosity (ROH), but the tumor cells show extensive $\mathrm{mLOH}$ from $11 \mathrm{p} 12$ to $11 \mathrm{p} 15$. $T$, tumor; $G$, germline; $F$, father; $M$, mother. $(A)$ Polymorphic markers electrophoresed by the PhastSystem. PYGM and D11S991 show ROH in the tumor cells, but D11S554, PAX6, and BDNF show mLOH in the tumor cells. (B) Polymorphic markers electrophoresed on a $2 \%$ agarose gel. TH and IGF2 show mLOH in the tumor cells.

Table 1. Extent of maternal LOH on $11 p$ in the present case

\begin{tabular}{|c|c|c|c|c|c|c|c|}
\hline Region & Locus & Method of detection & Tumor & Germline & Father & Mother & $\begin{array}{l}\text { Allele status of the } \\
\text { tumor cells }\end{array}$ \\
\hline $11 \mathrm{p} 13$ & $P Y G M$ & Compound $(\mathrm{CA})(\mathrm{GA})$ repeat & $\mathrm{A} / \mathrm{B}$ & $\mathrm{A} / \mathrm{B}$ & $\mathrm{A} / \mathrm{A}^{\prime}$ & $\mathrm{B} / \mathrm{B}^{\prime}$ & $\mathrm{ROH}$ \\
\hline $11 \mathrm{p} 11$ & D11S991 & Dinucleotide repeat & $\mathrm{A} / \mathrm{A}^{\prime}$ & $\mathrm{A} / \mathrm{A}^{\prime}$ & $\mathrm{A} / \mathrm{A}^{\prime}$ & $\mathrm{A} / \mathrm{A}^{\prime}$ & $\mathrm{ROH}$ \\
\hline $11 \mathrm{p} 13$ & WTA & RFLP and dinucleotide repeat & $\mathrm{A} / \mathrm{A} ?$ & $\mathrm{~A} / \mathrm{A}$ ? & $\mathrm{A} / \mathrm{A}^{\prime}$ & $\mathrm{A} / \mathrm{A}$ & NI \\
\hline $11 \mathrm{p} 13$ & PAX6 & Dinucleotide repeat & $\mathrm{A} /-$ & $\mathrm{A} / \mathrm{B}$ & $\mathrm{A} / \mathrm{A}^{\prime}$ & $\mathrm{A} / \mathrm{B}$ & $\mathrm{mLOH}$ \\
\hline $11 \mathrm{p} 13$ & $B D N F$ & Dinucleotide repeat & $\mathrm{A} /-$ & $\mathrm{A} / \mathrm{B}$ & $\mathrm{A} / \mathrm{A}$ & $\mathrm{B} / \mathrm{B}$ & $\mathrm{mLOH}$ \\
\hline $11 \mathrm{p} 15.5$ & $T H$ & Tetranucleotide repeat & $\mathrm{A} /-$ & $\mathrm{A} / \mathrm{B}$ & $\mathrm{A} / \mathrm{A}$ & $\mathrm{B} / \mathrm{B}$ & $\mathrm{mLOH}$ \\
\hline $11 \mathrm{p} 15.5$ & $I G F 2$ & RFLP & $\mathrm{A} /-$ & $\mathrm{A} / \mathrm{B}$ & $\mathrm{A} / \mathrm{A}$ & $\mathrm{B} / \mathrm{B}$ & $\mathrm{mLOH}$ \\
\hline $11 \mathrm{p} 15.5$ & $H 19$ & RFLP & $\mathrm{A} / \mathrm{A}$ ? & $\mathrm{A} / \mathrm{A}$ ? & $\mathrm{A} / \mathrm{A}$ & $\mathrm{A} / \mathrm{A}$ & NI \\
\hline
\end{tabular}

*A, A', B, and B' represent the respective alleles, $-=$ allele loss; ? = uncertain; $\mathrm{ROH}=$ retention of heterozygosity; $\mathrm{mLOH}=$ maternal $\mathrm{LOH} ; \mathrm{NI}=$ not informative.

term renal failure. However, because theirs is the only report to have described such findings, we have added a question mark, indicating that there is no clear evidence, in Table 3.

$\mathrm{LOH}$ on chromosome 11 was investigated in some of the previous cases, as shown in Table 2. In the present case, the lost allele was maternal, and $\mathrm{LOH}$ extended from $11 \mathrm{p} 12$ to $11 \mathrm{p} 15$. In the other cases, it was uncertain whether the lost allele was maternal or paternal, or how extensive the $\mathrm{LOH}$ was. LOH in $11 \mathrm{p} 15$ region has been suggested to be critical for WT tumorigenesis in certain cases (37), and a series of reports demonstrated the nonrandom maternal allele loss of $11 \mathrm{p}$ in the tumor cells of WT children $(38-40)$. Because there are several imprinted genes in $11 \mathrm{p} 15$, some of which may be related to WT tumorigenesis, LOH, especially the maternal loss of $11 \mathrm{p} 15$, may be critical for WT tumorigenesis in association with a WT1 mutation effect. For example, the constitutional genetic event in the WAGR patients is an $11 \mathrm{p} \mathrm{LOH}$, which is followed by a second hit WT1 mutation when the somatic cells transform to WT, whereas in the WT+GU patients, a constitutional WT1 mutation may be followed by a second hit $11 \mathrm{p}$ 

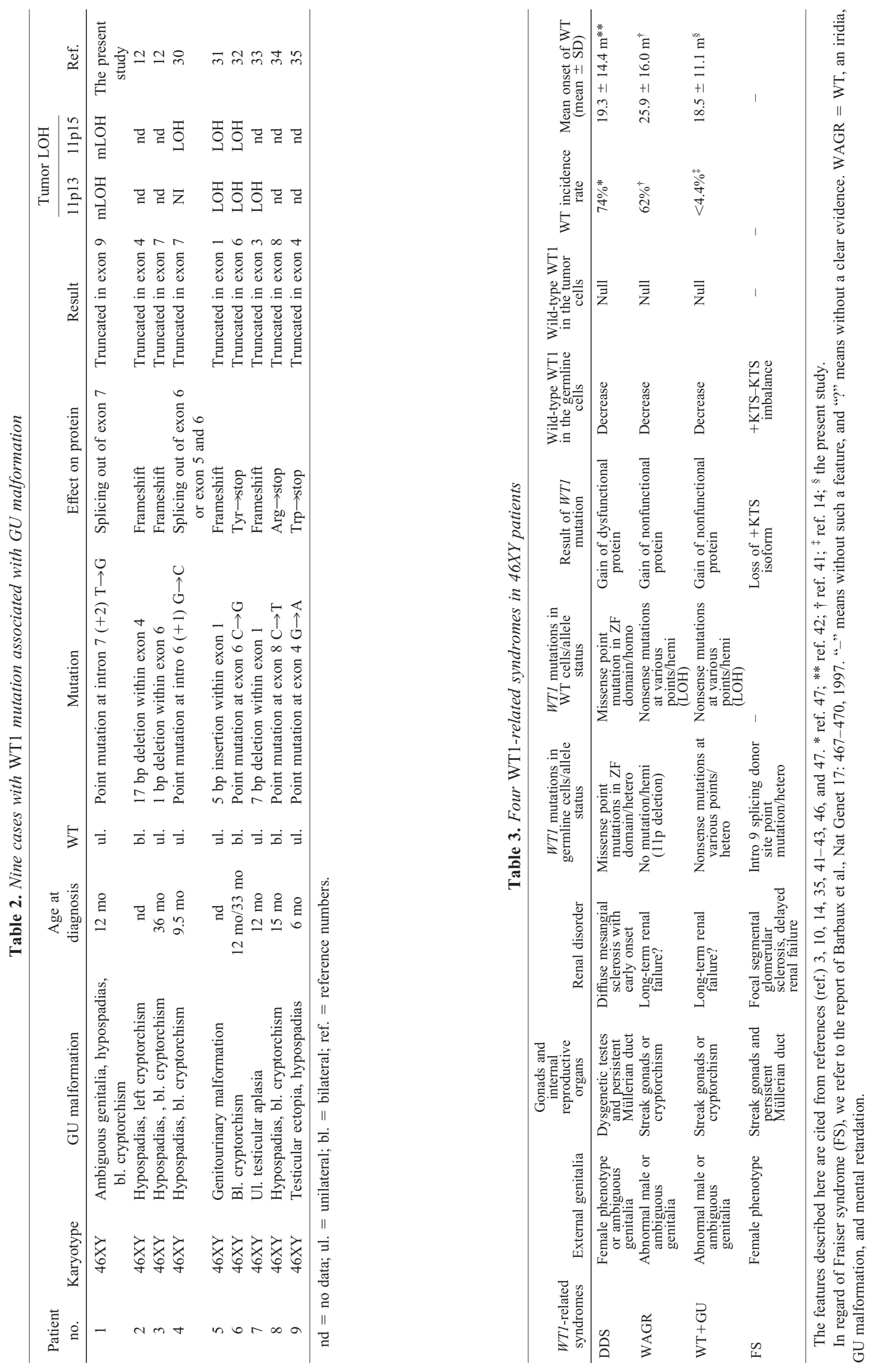
LOH (Table 3). Because meiotic recombinations are thought to be more frequent than mitotic recombinations, the higher risk of WT in the WAGR patients (62\%) (41) than in the WT+GU patients $(<4.4 \%)(14)$ could be explained by the probability of $\mathrm{LOH}$. However, to demonstrate the relation between $11 \mathrm{p} \mathrm{LOH}$ and $\mathrm{WT}$ tumorigenesis in $\mathrm{WT}+\mathrm{GU}$, more cases need to be accumulated, and it is recommended that polymorphic studies be carried out in WT + GU patients.

The patients described in Table 2 had an earlier onset of WT $[18.5 \pm 11.1$ mo (mean $\pm \mathrm{SD})]$ than in most WT cases (43.3 $\pm 31.6 \mathrm{mo}$ ) reported by Breslow et al. (3), suggesting that the presence of a predisposing WT1 mutation affects the onset, as shown in DDS patients $(13,42)$. In addition, all the WT1 mutations shown in Table 2 resulted in a truncated protein. Huff et al. (43) compared four cases that had been reported earlier (patients 2, 3, 4, and 5) with DDS patients in 1996. They hypothesized that the truncated protein is nonfunctional and causes GU malformation by a dose effect of decreasing normal WT1 protein, whereas the aberrant protein produced by the mutation in DDS is dysfunctional and induces additional, more severe symptoms, such as renal failure, as a result of a dominant-negative effect on an unknown target. However, both DDS and truncated WT1 mutants lose DNA binding activity for selected targets (44), and these mutants are known to associate with wild-type WT1 and act in a dominant-negative fashion if they retain the first 160 amino acids (45). These results suggest that both mutants act dominant-negatively. Additionally, the possibility of long-term renal failure in patients with WAGR or WT+GU has been suggested by a statistical study (36). Based on the results of these recent studies, we speculate that a decreasing dose of wild-type WT1 due to either mutant affects male GU malformation and causes long-term renal failure and that the dysfunctional DDS mutants may cause more severe GU anomalies, acute renal disorder (46), and an even higher incidence of WT (47), although their function remains to be elucidated.

The loss of WT1 expression within the tumor in the present case was demonstrated by the results of our immunohistochemical study. The regions suggesting nephrogenic rests also did not stain, and this further implies that the maternal allele was already lost in the nephrogenic rest cells, confirming the previous report of genetic events in the nephrogenic rests (48). Also, we found rich stromal components and ectopic myogenesis in the tumor. These findings are consistent with the previous report of a $W T 1$ null effect $(33,49)$. With respect to tumorigenesis, we must not overlook WT1 null effect. The complete loss of transcriptional regulation and/or apoptosis induced by the WT1 protein (50) may affect WT tumorigenesis in some cases, because the incidence of WT in patients with the WT1-related syndromes is definitely higher than in sporadic cases (Table 3). Baudry et al. (51) recently reported that they had found quantitative and/or qualitative alterations of WT1 mRNA expression, including WT1 splicing alterations, in $90 \%$ of sporadic WT. Their results may affect the present view of the relation between $W T 1$ and sporadic WT. In addition, although we did not demonstrate WT1 splicing variants expression, imbalance among them may also function in cases with $\mathrm{WT}+\mathrm{GU}$.

\section{REFERENCES}

1. Matsunaga E 1981 Genetics of Wilms' tumor. Hum Genet 57:231-246

2. Miller RW, Young Jr JL, Novakovic B 1995 Childhood cancer. Cancer 75:395-405

3. Breslow N, Olshan A, Beckwith JB, Green DM 1993 Epidemiology of Wilms tumor. Med Pediatr Oncol 21:172-181

4. Gessler M, Poustka A, Cavenee W, Neve RL, Orkin SH, Bruns GA 1990 Homozygous deletion in Wilms tumours of a zinc-finger gene identified by chromosome jumping. Nature 343:774-778

5. Call KM, Glaser T, Ito CY, Buckler AJ, Pelletier J, Haber DA, Rose EA, Kral A, Yeger H, Lewis WH, Jones C, Housman DE 1990 Isolation and characterization of a zinc finger polypeptide gene at the human chromosome 11 Wilms' tumor locus. Cell 60:509-520

6. Morris JF, Madden SL, Tournay OE, Cook DM, Sukhatme VP, Rauscher FJD 1991 Characterization of the zinc finger protein encoded by the WT1 Wilms' tumor locus. Oncogene 6:2339-2348

7. Madden SL, Cook DM, Morris JF, Gashler A, Sukhatme VP, Rauscher III FJ 1991 Transcriptional repression mediated by the WT1 Wilms tumor gene product. Science 253:1550-1553

8. Wang ZY, Qiu QQ, Enger KT, Deuel TF 1993 A second transcriptionally active DNA-binding site for the Wilms tumor gene product, WT1. Proc Natl Acad Sci U S A 90:8896-8900

9. Haber DA, Sohn RL, Buckler AJ, Pelletier J, Call KM, Housman DE 1991 Alternative splicing and genomic structure of the Wilms tumor gene WT1. Proc Natl Acad Sci U S A 88:9618-9622

10. Little M, Wells C 1997 A clinical overview of WT1 gene mutations. Hum Mutat 9:209-225

11. Kreidberg JA, Sariola H, Loring JM, Maeda M, Pelletier J, Housman D, Jaenisch R 1993 WT-1 is required for early kidney development. Cell 74:679-691

12. Pelletier J, Bruening W, Li FP, Haber DA, Glaser T, Housman DE 1991 WT1 mutations contribute to abnormal genital system development and hereditary Wilms' tumour. Nature 353:431-434

13. Pelletier J, Bruening W, Kashtan CE, Mauer SM, Manivel JC, Striegel JE, Houghton DC, Junien C, Habib R, Fouser L, Fine RN, Silverman BL, Haber DA, Housman D 1991 Germline mutations in the Wilms' tumor suppressor gene are associated with abnormal urogenital development in Denys-Drash syndrome. Cell 67:437-447

14. Pendergrass TW 1976 Congenital anomalies in children with Wilms' tumor: a new survey. Cancer 37:403-408

15. Diller L, Ghahremani M, Morgan J, Grundy P, Reeves C, Breslow N, Green D, Neuberg D, Pelletier J, Li FP 1998 Constitutional WT1 mutations in Wilms' tumor patients. J Clin Oncol 16:3634-640

16. Haber DA, Buckler AJ, Glaser T, Call KM, Pelletier J, Sohn RL, Douglass EC, Housman DE 1990 An internal deletion within an 11p13 zinc finger gene contributes to the development of Wilms' tumor. Cell 61:1257-1269

17. Gessler M, Konig A, Bruns GA 1992 The genomic organization and expression of the WT1 gene. Genomics 12:807-813

18. Varanasi R, Bardeesy N, Ghahremani M, Petruzzi MJ, Nowak N, Adam MA, Grundy P, Shows TB, Pelletier J 1994 Fine structure analysis of the WT1 gene in sporadic Wilms tumors. Proc Natl Acad Sci U S A 91:3554-3558

19. Iwasaki H, Stewart PW, Dilley WG, Holt MS, Steinbrueck TD, Wells Jr SA, Donis-Keller H 1992 A minisatellite and a microsatellite polymorphism within $1.5 \mathrm{~kb}$ at the human muscle glycogen phosphorylase (PYGM) locus can be amplified by PCR and have combined informativeness of PIC 0.95. Genomics 13:7-15

20. Broman KW, Murray JC, Sheffield VC, White RL, Weber JL 1998 Comprehensive human genetic maps: individual and sex-specific variation in recombination. Am J Hum Genet 63:861-869

21. Phromchotikul T, Browne D, Litt M 1992 Microsatellite polymorphisms at the D11S554 and D11S569 loci. Hum Mol Genet 1:214

22. Tadokoro K, Oki N, Sakai A, Fujii H, Ohshima A, Nagafuchi S, Inoue T, Yamada M 1993 PCR detection of 9 polymorphisms in the WT1 gene. Hum Mol Genet 2:2205-2206

23. Martha AD, Ferrell RE, Saunders GF 1993 Dinucleotide repeat polymorphism in the human aniridia (PAX6) gene. Hum Mol Genet 2:1982

24. Proschel M, Saunders A, Roses AD, Muller CR 1992 Dinucleotide repeat polymorphism at the human gene for the brain-derived neurotrophic factor (BDNF). Hum Mol Genet 1:353

25. Hudson TJ, Engelstein M, Lee MK, Ho EC, Rubenfield MJ, Adams CP, Housman DE, Dracopoli NC 1992 Isolation and chromosomal assignment of 100 highly informative human simple sequence repeat polymorphisms. Genomics 13:622-629

26. Parkinson DB, Shaw NJ, Himsworth RL, Thakker RV 1993 Parathyroid hormone gene analysis in autosomal hypoparathyroidism using an intragenic tetranucleotide (AAAT)n polymorphism. Hum Genet 91:281-284

27. Polymeropoulos MH, Xiao H, Rath DS, Merril CR 1991 Tetranucleotide repeat polymorphism at the human tyrosine hydroxylase gene (TH). Nucleic Acids Res 19:3753

28. Tadokoro K, Fujii H, Inoue T, Yamada M 1991 Polymerase chain reaction (PCR) for detection of $A p a \mathrm{I}$ polymorphism at the insulin like growth factor II gene (IGF2). Nucleic Acids Res 19:6967

29. Jinno Y, Sengoku K, Nakao M, Tamate K, Miyamoto T, Matsuzaka T, Sutcliffe JS, Anan T, Takuma N, Nishiwaki K, Ikeda Y, Ishimaru T, Ishikawa M, Niikawa N 1996 Mouse/human sequence divergence in a region with a paternal-specific methylation imprint at the human H19 locus. Hum Mol Genet 5:1155-61

30. Schneider S, Wildhardt G, Ludwig R, Royer-Pokora B 1993 Exon skipping due to a mutation in a donor splice site in the WT-1 gene is associated with Wilms' tumor and severe genital malformations. Hum Genet 91:599-604 
31. Huff V, Jaffe N, Saunders GF, Strong LC, Villalba F, Ruteshouser EC 1995 WT1 exon 1 deletion/insertion mutations in Wilms tumor patients, associated with di- and trinucleotide repeats and deletion hotspot consensus sequences. Am J Hum Genet 56:84-90

32. Nordenskjold A, Friedman E, Sandstedt B, Soderhall S, Anvret M 1995 Constitutional and somatic mutations in the WT1 gene in Wilms' tumor patients. Int J Cancer 63:516-522

33. Schumacher V, Schneider S, Figge A, Wildhardt G, Harms D, Schmidt D, Weirich A, Ludwig R, Royer-Pokora B 1997 Correlation of germ-line mutations and two-hit inactivation of the WT1 gene with Wilms tumors of stromal-predominant histology. Proc Natl Acad Sci U S A 94:3972-7

34. Kohler B, Schumacher V, Schulte-Overberg U, Biewald W, Lennert T, l'Allemand D, Royer-Pokora B, Gruters A 1999 Bilateral Wilms tumor in a boy with severe hypospadias and cryptochidism due to a heterozygous mutation in the WT1 gene. Pediatr Res 45:187-190

35. Jeanpierre C, Denamur E, Henry I, Cabanis MO, Luce S, Cecille A, Elion J, Peuchmaur M, Loirat C, Niaudet P, Gubler MC, Junien C 1998 Identification of constitutional WT1 mutations, in patients with isolated diffuse mesangial sclerosis, and analysis of genotype/phenotype correlations by use of a computerized mutation database. Am J Hum Genet 62:824-833

36. Breslow NE, Takashima JR, Ritchey ML, Strong LC, Green DM 2000 Renal failure in the Denys-Drash and Wilms' tumor-aniridia syndromes. Cancer Res 60:4030-4032

37. Reeve AE, Sih SA, Raizis AM, Feinberg AP 1989 Loss of allelic heterozygosity at a second locus on chromosome 11 in sporadic Wilms' tumor cells. Mol Cell Biol 9:1799-1803

38. Schroeder WT, Chao LY, Dao DD, Strong LC, Pathak S, Riccardi V, Lewis WH, Saunders GF 1987 Nonrandom loss of maternal chromosome 11 alleles in Wilms tumors. Am J Hum Genet 40:413-420

39. Williams JC, Brown KW, Mott MG, Maitland NJ 1989 Maternal allele loss in Wilms' tumour [letter]. Lancet 1:283-284

40. Jeanpierre C, Antignac C, Beroud C, Lavedan C, Henry I, Saunders G, Williams B, Glaser T, Junien C 1990 Constitutional and somatic deletions of two different regions of maternal chromosome 11 in Wilms tumor. Genomics 7:434-438
41. Narahara K, Kikkawa K, Kimira S, Kimoto H, Ogata M, Kasai R, Hamawaki M, Matsuoka K 1984 Regional mapping of catalase and Wilms tumor-aniridia, genitourinary abnormalities, and mental retardation triad loci to the chromosome segment 11p1305-p1306. Hum Genet 66:181-185

42. Jadresic L, Leake J, Gordon I, Dillon MJ, Grant DB, Pritchard J, Risdon RA, Barratt TM 1990 Clinicopathologic review of twelve children with nephropathy, Wilms tumor, and genital abnormalities (Drash syndrome). J Pediatr 117:717-725

43. Huff V 1996 Genotype/phenotype correlations in Wilms' tumor. Med Pediatr Oncol 27:408-414

44. Little M, Holmes G, Bickmore W, van Heyningen V, Hastie N, Wainwright B 1995 DNA binding capacity of the WT1 protein is abolished by Denys-Drash syndrome WT1 point mutations. Hum Mol Genet 4:351-358

45. Moffett P, Bruening W, Nakagama H, Bardeesy N, Housman D, Housman DE, Pelletier J 1995 Antagonism of WT1 activity by protein self-association. Proc Natl Acad Sci U S A 92:11105-11109

46. Manivel JC, Sibley RK, Dehner LP 1987 Complete and incomplete Drash syndrome: a clinicopathologic study of five cases of a dysontogenetic-neoplastic complex. Hum Pathol 18:80-89

47. Mueller RF 1994 The Denys-Drash syndrome. J Med Genet 31:471-477

48. Charles AK, Brown KW, Berry PJ 1998 Microdissecting the genetic events in nephrogenic rests and Wilms' tumor development. Am J Pathol 153: 991-1000

49. Miyagawa K, Kent J, Moore A, Charlieu JP, Little MH, Williamson KA, Kelsey A, Brown KW, Hassam S, Briner J, Hayashi Y, Hirai H, Yazaki Y, van Heyningen V, Hastie ND 1998 Loss of WT1 function leads to ectopic myogenesis in Wilms' tumour. Nat Genet 18:15-17

50. Englert C, Hou X, Maheswaran S, Bennett P, Ngwu C, Re GG, Garvin AJ, Rosner MR, Haber DA 1995 WT1 suppresses synthesis of the epidermal growth factor receptor and induces apoptosis. EMBO J 14:4662-4675

51. Baudry D, Hamelin M, Cabanis MO, Fournet JC, Tournade MF, Sarnacki S, Junien C, Jeanpierre C 2000 WT1 splicing alterations in Wilms' tumors. Clin Cancer Res 6:3957-3965 